\title{
Effect of using HEART score in patients with chest pain at the emergency department of University Clinical Centre of the Republic of Srpska
}

\section{Bojan M. Stanetić', Nenad Jaćimović, Šemsudin Porčić ${ }^{2}$}

'University Clinical Centre of the Republic of Srpska, Department of Cardiology, Banja Luka, The Republic of Srpska, Bosnia and Herzegovina

2University of Banja Luka, Medical Faculty, Banja Luka, The Republic of Srpska, Bosnia and Herzegovina

Primljen - Received: 13/12/2020

Prihvaćen - Accepted: 26/01/2021

\section{Corresponding author:}

Bojan Stanetić, PhD

Vojvode Stepe Stepanovića 82, 78000

Banja Luka

bojan.stanetic@gmail.com

Copyright: @2021 Bojan M. Stanetić et all. This is an Open Access article distributed under the terms of the Creative Commons Attribution 4.0 International (CC BY 4.0) license.

\begin{abstract}
Summary
Introduction. Recent data show that $1 / 5$ of patients with chest pain in emergency room (ER) have an acute coronary syndrome that requires admission and treatment. Current guidelines have endorsed the HEART score for admission, observation or discharge in individual patients. We aimed to assess performance of the HEART score at the University Clinical Centre of the Republic of Srpska.
\end{abstract}

Methods. Between March 1 and March 31, 2019, all patients with chest pain who presented at ER were evaluated. The HEART score for each patient was calculated, and patients were stratified based on the HEART score recommendation, i.e. low-, intermediate- and high-risk. Patients were followed 6 weeks for major adverse cardiac events (MACE).

Results. Out of a total of 144 included patients, 23 had low-risk (0-3) HEART scores, while 73 and 48 patients had intermediate-risk (4-6) and high-risk (7-10) HEART scores, respectively. The discordance among intuitive judgments by clinicians and the HEART score advice became typically obtrusive in patients with excessive (7-10) HEART score rankings: 25 out of 48 (52.1\%) patients had been discharged, while the remaining 22 patients had been admitted and 1 person was observed. In population with HEART score rankings 4-6, MACE became recognized in $1 / 73(1.4 \%)$ while in patients with excessive HEART score rankings (values 7-10), MACE befell in $5 / 48$ (10.4\%). Only one patient who was discharged experienced MACE. The ROC analysis of the HEART score revealed a value of 0.78 , suggesting a good performance in discriminating between low- and high-risk patients.

Conclusion. Discordance between clinical decision and HEART score recommendation was not associated with severe clinical consequences.

Keywords: heart score, emergency room, chest pain

\section{Introduction}

Patients with chest pain are very common in an emergency department (ED) [1]. However, only $1 / 5$ of patients with chest pain have an acute coronary syndrome (ACS) that requires admission and treatment. In the vast majority, the underlying condition is non-cardiac and these patients can be safely discharged from the ER and treated in an outpatient clinic [2]. However, 
typical chest pain is present in only half of the patients with ACS [3] which is the reason that $2-6 \%$ of patients with ACS are not timely recognized [4,5]. In addition, clinicians tend to postpone their decisions and to confess those patients for medical observation, and to deal with them as patients with ACS. Consequently, over-diagnosing and needless remedy are common.

Recent trials have shown that risk scoring systems are superior to clinical assessment in identifying high-risk population [6-9]. Therefore, current guidelines have endorsed the HEART score which was designed to improve risk stratification of all-cause chest pain patients at the ED [10]. It consists of five parameters in the initial assessment of patients with chest pain: medical history, electrocardiogram, age, risk factors, and high sensitive troponin value [11]. Each of the parameters can be scored with 0,1 or 2 points (Figure 1 ). Importantly, the HEART score is based on clinical experience with simple bed-side applicability, and provides physicians with a recommendation for admission, observation, or discharge in individual patients. The diagnostic utility of the HEART score has been confirmed in many studies [12-15].

In the present study, we aimed to assess performance of the HEART score in tertiary institution with real-world everyday population.

\section{Methods}

Between March 1 and March 31, 2019, all patients with chest pain who presented at ER of University Clinical Centre of the Republic of Srpska were evaluated. Presenters with symptoms of dyspnea or palpitations were not included. Patients with ST-segment elevation myocardial infarction at admission were excluded. The HEART score for each patient was calculated, and patients were stratified based on the HEART score recommendation. The study became authorized via way

\section{HEART}

HEART score for chest pain patients

\begin{tabular}{|c|c|c|}
\hline \multirow{3}{*}{$\begin{array}{l}\text { History } \\
\text { (Anamnesis) }\end{array}$} & Highly suspicious & 2 \\
\hline & Moderately suspicious & 1 \\
\hline & Slightly suspicious & 0 \\
\hline \multirow[t]{3}{*}{ ECG } & Significant ST-deviation & 2 \\
\hline & $\begin{array}{l}\text { Non-specific repolarisation } \\
\text { disturbance / LBBB / PM }\end{array}$ & 1 \\
\hline & Normal & 0 \\
\hline \multirow[t]{3}{*}{$\underline{A g e}$} & $\geq 65$ years & 2 \\
\hline & $45-65$ years & 1 \\
\hline & $\leq 45$ years & 0 \\
\hline \multirow[t]{3}{*}{ Risk factors } & $\begin{array}{l}\geq 3 \text { risk factors or history of } \\
\text { atherosclerotic disease }\end{array}$ & 2 \\
\hline & 1 or 2 risk factors & 1 \\
\hline & No risk factors known & 0 \\
\hline \multirow[t]{3}{*}{ Iroponin } & z 3x normal limit & 2 \\
\hline & $1-3 \times$ normal limit & 1 \\
\hline & $\leq$ normal limit & 0 \\
\hline \multicolumn{3}{|c|}{ Total } \\
\hline
\end{tabular}

\begin{tabular}{|c|c|}
\hline \multicolumn{2}{|c|}{ Risk factors for atherosclerotic disease: } \\
\hline Hypercholesterolemia & Cigarette smoking \\
\hline Hypertension & Positive family history \\
\hline Diabetes Mellitus & Obesity $(\mathrm{BM}>30)$ \\
\hline
\end{tabular}

Figure 1. Original HEART score, with permission of the authors. BMI, body mass index; LBBB, left bundle branch block; PM, pacemaker

of means of nearby ethics committee. As this became an observational non-intervention study, knowledgeable consent strategies had been waived.

Data acquisition consisted of separate entries for classical factors of affected person history, cardiovascular threat factors, medication, physical exam and beyond clinical history. Laboratory values which include high-sensitive troponin $\mathrm{T}$ have been accrued for the time being of admission. Only the first troponin T value became used for the HEART score calculation. Follow-up have been retrieved from electronic and written records, which included discharge letters, revascularization reviews and some other applicable documentation. The diagnosis of acute myocardial infarction was made according to the applicable guidelines. Therefore, non ST-elevation myocardial 
infarction was defined as a syndrome consisting of a rise of high-sensitive troponin values, typical patient history and persistent or transient ST-segment depression or T-wave inversion, flat T-waves, pseudo-normalization of T-waves, or no changes at presentation. As a percutaneous coronary intervention was considered any therapeutic catheter intervention in the epicardial arteries, while coronary artery bypass graft surgery was defined as any surgery in which epicardial arteries were operated on.

During the six-week follow-up of the initial presentation, following major adverse cardiac events (MACE) were collected: acute myocardial infarction, percutaneous coronary intervention, coronary artery bypass graft surgery, coronary angiography revealing procedurally correctable stenosis managed conservatively, and all-cause death.

Statistical analysis was performed with SPSS (Version 25; MAC). Descriptive statistics are given as mean $+/-$ standard deviation or median $+/$ - interquartile range, based on the distribution of continuous variables. Categorical variables were presented as a number with a percentage. Differences between means were assessed through the Student's t-test when normally distributed or Mann Whitney U-test when not normally distributed. The probability of reaching an endpoint was calculated as the percentage of cases with an endpoint within a given category. Kaplan-Meier analysis was used to assess differences in outcome of low-, intermediate- and high-risk patients. The ability of the HEART score in discriminating between low- and high-risk was described by the Receiving Operating Curves (ROC) analysis. It estimates the probability that, of 2 randomly chosen patients, the patient with more favorable prognostic score will surpass the patient with less favorable prognostic score and ranges from 0.5 (no discrimination) to the theoretical maximum of 1 .

\section{Results}

Out of 932 patients presented to the ER, 788 did not meet inclusion criteria. Out of a total of 144 included patients, 23 had low-risk (0-3) HEART scores, while 73 and 48 patients had intermediate-risk (4-6) and high-risk (7-10) HEART scores, respectively. There were higher incidence of arterial hypertension, type 2 diabetes mellitus and coronary artery disease within the high-risk group (Table 1). The discordance between ",intuitive“ judgments and HEART score advise was mostly prominent in patients with highest (7-10) HEART scores: 25 out of 48 (52.1\%) patients were discharged, while the remaining 22 were immediately admitted and 1 patient was observed (Table 2).

During the follow-up (Figure 2), six (4.2\%) patients have experienced MACE within six weeks: acute myocardial infarction was diagnosed in 4 patients of which 2 patients presented with STEMI, 2 patients underwent PCI, 0 patients had a CABG and 2 patients had coronary angiography revealing angiographically significant epicardial stenosis. In patients with intermediate HEART scores ranking of 4-6, MACE was found in 1/73 $(1.4 \%)$. On the other side, in patients with highest HEART scores (values 7-10), MACE occurred in 5/48 (10.4\%). One patient from the high-risk group, who was discharged, experienced MACE within 6 weeks. The ROC analysis of the HEART score revealed a value of 0.78 (95\% confidence interval 0.74-0.82; $\mathrm{p}=0.01$ ), suggesting a good performance of the HEART score in discriminating between lowand high-risk patients.

\section{Discussion}

Chest pain is one of the most common complaints among patients presented in the ER. Failure to identify a patient's chest pain cause put the risk of sustaining missed acute coronary syndrome which may lead to significantly 
Table 1. Baseline characteristics

HEART SCORE

\begin{tabular}{lccccc}
\hline VARIABLE & $\begin{array}{c}\text { LOW } \\
(\mathbf{n}=\mathbf{2 3})\end{array}$ & $\begin{array}{c}\text { MODERATE } \\
(\mathbf{n}=\mathbf{7 3})\end{array}$ & $\begin{array}{c}\text { HIGH } \\
(\mathbf{n = 4 8 )}\end{array}$ & p-value & $\begin{array}{c}\text { TOTAL } \\
(\mathbf{n = 1 4 4 )}\end{array}$ \\
\hline Arterial hypertension & $6(26.1 \%)$ & $54(74.0 \%)$ & $42(87.5 \%)$ & $<0.001$ & $102(70.8 \%)$ \\
Type 2 diabetes mellitus & $0(0.0 \%)$ & $11(15.1 \%)$ & $14(29.2 \%)$ & 0.008 & $25(17.4 \%)$ \\
Coronary artery disease & $4(17.4 \%)$ & $19(26.0 \%)$ & $34(70.8 \%)$ & $<0.001$ & $57(39.6 \%)$ \\
Dyslipidemia & $0(0.0 \%)$ & $2(2.7 \%)$ & $2(4.2 \%)$ & 0.606 & $4(2.8 \%)$ \\
Obesity & $1(4.3 \%)$ & $0(0.0 \%)$ & $1(2.1 \%)$ & 0.263 & $2(1.4 \%)$ \\
Smoking & $3(13.0 \%)$ & $3(4.1 \%)$ & $2(4.2 \%)$ & 0.232 & $8(5.6 \%)$ \\
High-sensitive Troponin T & $8.7 \pm 14.8$ & $38.7 \pm 71.9$ & $327.6 \pm$ & 0.164 & $130.2 \pm$ \\
Serum Creatinine & $58.5 \pm 31.2$ & $101.0 \pm 85.3$ & $86.0 \pm 94.2$ & 0.404 & $91.5 \pm 84.4$ \\
Hemoglobine & $145.2 \pm 15.6$ & $102.0 \pm 55.2$ & $113.7 \pm 49.8$ & 0.034 & $112.5 \pm 51.1$ \\
Male & $15(65.2 \%)$ & $34(46.6 \%)$ & $29(60.4 \%)$ & 0.167 & $78(54.2 \%)$ \\
Age & $68.8 \pm 12.9$ & $71.1 \pm 12.0$ & $66.2 \pm 12.9$ & 0.533 & $69.3 \pm 12.3$ \\
\hline
\end{tabular}

Data given as mean \pm standard deviation or $\mathrm{n}(\%)$

higher clinical consequences [16]. The appropriately use of the HEART score gives the clinician reliable prediction of outcome, and importantly, very soon after the patients arrival. Our study showed that no MACE occurred among those low-risk HEART score. When taken into account, low-risk HEART score criteria may fail in $2 \%$ of patients only who develop MACE [17]. One study reported that acceptable miss rate of MACE would be around 1\% [17].

The results of our study are similar to those previously reported by Van Den Berg and Body showing easy clinical applicability of the HEART score in everyday routine [18].
Nowadays, many risk scoring systems were developed with an aim to aid clinicians in their decision-making [19]. The most common of these are the TIMI- and GRACE-scores, who were developed to stratify patients in coronary units. Although not designed for the purpose excluding the acute coronary syndrome in unselected population, these scores are applied at ER for the whole range of chest pain patients. On the contrary, the HEART score was specifically designed for the population with chest discomfort at ER. Probably the best value of the HEART score is easy, bed-side applicability, especially having in

Table 2. Adherence to the Heart score

\begin{tabular}{ccccc}
\hline Heart score & Discharge & Observe & Admission & Total \\
\hline Low & 19 & 1 & 3 & 23 \\
Intermediate & 54 & 5 & 14 & 73 \\
High & 25 & 1 & 22 & 48 \\
Total & 98 & 7 & 39 & 144 \\
\hline
\end{tabular}




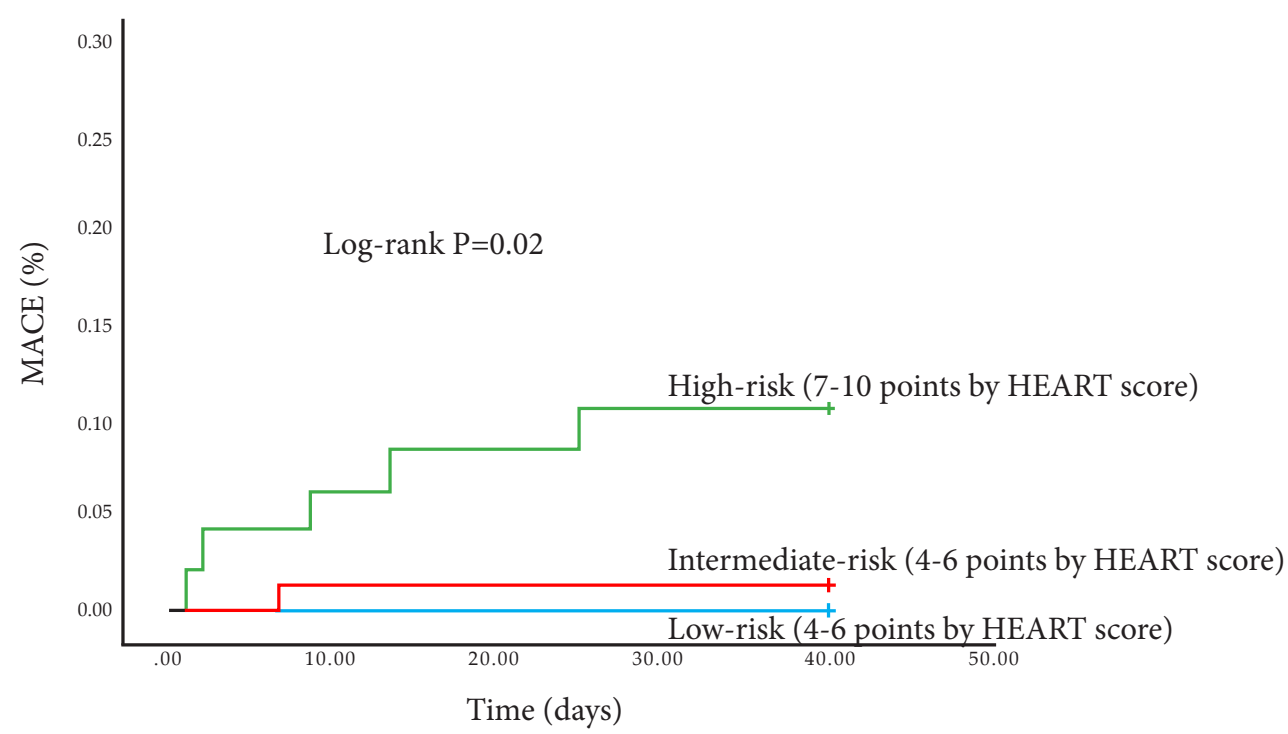

Figure 2. Kaplan-Meier analysis. The cumulative incidence rates of major adverse cardiac events between low-, intermediate- and high-risk group stratified by HEART score at 6-week follow-up

mind the fact that it uses admission data only, typically complete within $1 \mathrm{~h}$ of initial assessment. There are some well-validated prediction models of death, for example the GRACE score. However, practical disadvantage of the GRACE score lies in fact that it can be calculated by computer only. The TIMI score, developed more than 25 years ago, was able to identify high-risk patients who may benefit from aggressive anticlotting agents, and was relatively easy to calculate. However, it was quite rough since it allowed binary choices only, and therefore ignored the fact that many variables have a 'grey area'.

Recently, a comparison of GRACE, TIMI and HEART scores in terms of predictive capabilities was done, and showed that the HEART score (c-index 0.83) is the best score to exclude acute coronary syndrome at ER, while GRACE (c-index 0.70) and TIMI (c-index 0.75) scores should be reserved for hospitalized patients [20]. Our analysis revealed the c-index of the HEART score of 0.78 meaning that the HEART score has retained its performance in our population.
Each element of the HEART score is important in forming predicition. The score follows clinical decision-making and can be used as a helpful tool to correctly stratify patients into low, intermediate- or high-risk. However, probably the main issue represents usage of different cutoff values and low specificity of troponin measurements. In practice, this may result that some patients with slightly elevated troponins may be overclassified into the high-risk group. This may be the reason for high percentage $(52.1 \%)$ of discrepancy between clinical decisions and HEART score recommendation. However, this had no severe clinical consequences.

In conclusion, we confirmed that the HEART score is a quick, easy and reliable predictor of MACE, without computer-required calculating. Low HEART scores (0-3), exclude short-term MACE with very high certainty, and these patients can be safely discharged. In contrast, patients with high HEART scores (7-10) may indicate more aggressive policies.

The present analysis had several limitations as well as advantages: (1) the low number of patients - however, our patients came 
from everyday routine; (2) data collection was suboptimal - we were not able to sample more data on patients comorbidities; (3) since this was not a randomized study, it could not deal with possible confounders which may guide clinicians in the decision-making process.
Funding source. The authors received no specific funding for this work.

Ethical approval. The Ethics Committee of the University Clinical Centre of the Republic of Srpska approved the study and informed consent was obtained from all the individual

\section{References:}

1. Goodacre S, Cross E, Arnold J, Angelini K, Capewell S, Nicholl J. The health care burden of acute chest pain. Heart 2005;91:229-30.

2. Lee TH, Goldman L. Evaluation of the patient with acute chest pain. $\mathrm{N}$ Engl J Med 2000;342:1187-95.

3. Carlton EW, Than M, Cullen L, Khattab A, Greaves K. 'Chest pain typicality' in suspected acute coronary syndromes and the impact of clinical experience. Am J Med 2015;128:1109-16.

4. Pope JH, Aufderheide TP, Ruthazer R, Woolard RH, Feldman JA,Beshansky JR, et al. Missed diagnoses of acute cardiac ischemia in the emergency department. N Engl J Med 2000; 342:1163-70.

5. Christenson J, Innes G, McKnight D, Boychuk B, Grafstein E, Thompson CR, et al. Safety and efficiency of emergency department assessment of chest discomfort. CMAJ 2004;170:1803-17.

6. Goldman L, Cook EF, Johnson PA, Brand DA, Rouan GW, Lee TH. Prediction of the need for intensive care in patients who come to emergency departments with acute chest pain. $\mathrm{N}$ Engl J Med 1996;334:1498-504.

\section{Conclusion}

The HEART score is a quick and reliable predictor of MACE. Discordance between clinical decision and HEART score recommendation was not associated with severe clinical consequences. However, there is no risk-scoring system that can replace careful multidisciplinary clinical decision-making. The HEART score seems to be a helpful tool in this process.

respondents. The research was conducted according to the Declaration of Helsinki.

Conflicts of interest. The authors declare no conflict of interest.

7. Lee TH, Juarez G, CookEF, Weisberg MC, Rouan GW, Brand DA, et al. Ruling out acute myocardial infarction. A prospective multicenter validation of a 12-hour strategy for patients at low risk. N Engl J Med 1991;324:1239-46.

8. Goldman L, Cook EF, Brand DA, Lee TH, Rouan GW, WeisbergMC, et al. A computer protocol to predict myocardial infarction in emergency department patients with chest pain. N Engl J Med 1988;318:797-803.

9. Reilly BM, Evans AT, Schaider JJ, Das K, Calvin JE, Moran LA, et al. Impact of a clinical decision rule on hospital triage of patients with suspected acute cardiac ischemia in the emergency department. JAMA 2002;288:342-50.

10. Roffi M, Patrono C, Collet JP, Mueller C, Valgimigli M, Andreotti F, et al; Management of Acute Coronary Syndromes in Patients Presenting without Persistent ST-Segment Elevation of the European Society of Cardiology. 2015 ESC guidelines for the management of acute coronary syndromes in patients presenting without persistent ST-segment elevation: Task Force for the Management of Acute Coronary Syndromes in Patients Presenting without Persistent STSegment Elevation of the European Society of Cardiology (ESC). Eur Heart J 2016;37:267-315. 
11. Six AJ, Backus BE, Kelder JC. Chest pain in the emergency room: value of the HEART score. Neth Heart J 2008;16:191-6.

12. Six AJ, Cullen L, Backus BE, Greenslade J, Parsonage W, Aldous $S$, et al. The HEART score for the assessment of patients with chest pain in the emergency department: a multinational validation study. Crit Pathw Cardiol 2013;12:121-6.

13. Mahler SA, Hiestand BC, Goff DC Jr, Hoekstra JW, Miller CD. Can the HEART score safely reduce stress testing and cardiac imaging in patients at low risk for major adverse cardiac events? Crit Pathw Cardiol 2011;10:128-33.

14. Mahler SA, Miller CD, Hollander JE, Nagurney JT, Birkhahn R, Singer AJ, et al. Identifying patients for early discharge: performance of decision rules among patients with acute chest pain. Int J Cardiol 2013;168:795-802.

15. Mahler SA, Riley RF, Hiestand BC, Russell GB, Hoekstra JW, Lefebvre CW, et al. The HEART Pathway randomized trial: identifying emergency department patients with acute chest pain for early discharge. Circ Cardiovasc Qual Outcomes 2015;8:195-203.

16. Fox KA, Carruthers KF, Dunbar DR, et al. Underestimated and underrecognized: the late consequences of acute coronary syndrome (GRACE UK-Belgian Study). Eur Heart J 2010;31:2755-64.

17. Than M, Herbert M, Flaws D, et al. What is an acceptable risk of major adverse cardiac event in chest pain patients soon after discharge from the emergency department a clinical survey. Int J Cardiol 2013;166:752-4.

18. Van Den Berg P, Body R. The HEART score for early rule out of acute coronary syndromes in the emergency department: a systematic review and meta-analysis. Eur Heart J Acute Cardiovasc Care 2018;7:111-9.

19. de Araújo Gonçalves P, Ferreira J, Aguiar C, Seabra-Gomes R. TIMI, PURSUIT, and GRACE risk scores: sustained prognostic value and interaction with revascularization in NSTE-ACS. Eur Heart J 2005;26:865-72.

20. Backus BE, Six AJ, Kelder JC, Bosschaert MA, Mast EG, Mosterd A, Veldkamp RF, Wardeh AJ, Tio R, Braam R, Monnink SH, van Tooren $\mathrm{R}$, Mast TP, van den Akker F, Cramer MJ, Poldervaart JM, Hoes AW, Doevendans PA. A prospective validation of the HEART score for chest pain patients at the emergency department. Int J Cardiol 2013;168(3):2153-8. 


\title{
Efekat upotrebe HEART skora kod pacijenata sa bolom u grudima u Urgentnom centru Univerzitetskog kliničkog centra Republike Srpske
}

\author{
Bojan M. Stanetić', Nenad Jaćimovićz ${ }^{2}$ Šemsudin Porčić \\ 'Univerzitetski klinički centar Republike Srpske, Odsjek za kardiologiju, Banja Luka, \\ Republika Srpska, Bosna i Hercegovina \\ 2Univerzitet u Banjoj Luci, Medicinski Fakultet, Banja Luka, Republika Srpska, Bosna i Hercegovina
}

\begin{abstract}
Uvod. Najnoviji podaci pokazuju da 1/5 pacijenata s bolom u grudima koji se jave u Urgentni centar (UC) ima akutni koronarni sindrom koji zahtijeva prijem i liječenje. Trenutne smjernice prihvatile su HEART skor za prijem, posmatranje ili otpust kod pojedinačnih pacijenata. Cilj nam je bio da procijenimo značaj HEART skora na pacijente sa bolom u grudima u Univerzitetskom kliničkom centru Republike Srpske.
\end{abstract}

Metode. Analiza je obuhvatila period od 1. do 31. marta 2019. godine i uključila je sve pacijente sa bolom u grudima koji su se javili u UC. Za svakog pacijenta izračunat je HEART skor, a pacijenti su podijeljeni na osnovu preporuke HEART skora, tj. pacijenti sa niskim, srednjim i visokim rizikom. Pacijenti su praćeni šest nedjelja, zbog većih neželjenih kardiovaskularnih događaja (VNKD).

Rezultati. Od ukupno 144 uključena bolesnika, 23 su svrstana u grupu niskog rizika (HEART skor 0-3), dok 73 i 48 pacijenata je kategorisano kao srednje rizični (HEART skor 4-6), odnosno visoko rizični (HEART skor 7-10). Najveći nesklad između intuitivne procjene kliničara i preporuke HEART skora je primijećen u grupi visokog: čak 25 od $48(52,1 \%)$ pacijenata je otpušteno, dok su preostala 22 pacijenta primljena, tj. jedan pacijent je posmatran. $U$ populaciji srednjeg rizika, VNKD se desio kod 1/73 bolesnika (1,4\%), dok je kod pacijenata s visokim rizikom konstatovano 5/48 VNKD (10,4\%). Samo je jedan otpušteni pacijent doživio VNDK. ROC analiza HEART skora pokazala je vrijednost od 0,78 , što sugeriše dobru prediktivnu sposobnost u razlikovanju pacijenata s niskim i visokim rizikom.

Zaključak. Nesklad između kliničke odluke i preporuke HEART skora nije povezan s ozbiljnim kliničkim posljedicama.

Ključne riječi: HEART skor, urgentni centar, bol u grudima 